\title{
Judicious Use of Lipid Lowering Agents in the Management of NAFLD
}

\author{
Umair Iqbal ${ }^{1}$, Brandon J. Perumpail ${ }^{2}$, Nimy John ${ }^{3}$, Sandy Sallam ${ }^{3}$, Neha D. Shah ${ }^{3}$, \\ Waiyee Kwong ${ }^{3}$, George Cholankeril ${ }^{3}$, Donghee Kim ${ }^{3}{ }^{3}$ and Aijaz Ahmed ${ }^{3, *(D)}$ \\ 1 Department of Medicine, Geisinger Medical Center, Danville, PA 17821, USA; umairiqbal_dmc@hotmail.com \\ 2 Drexel University College of Medicine, Philadelphia, PA 19104, USA; brandonperumpail@gmail.com \\ 3 Division of Gastroenterology and Hepatology, Stanford University School of Medicine, Stanford, \\ CA 94304, USA; nionnj@gmail.com (N.J.); SSallam@stanfordhealthcare.org (S.S.); \\ NeShah@stanfordhealthcare.org (N.D.S.); WKwong@stanfordhealthcare.org (W.K.); \\ georgetc@stanford.edu (G.C.); dhkimmd@stanford.edu (D.K.) \\ * Correspondence: aijazahmed@stanford.edu; Tel.: +650-498-5691; Fax: +650-498-5692
}

Received: 9 August 2018; Accepted: 16 September 2018; Published: 24 September 2018

\begin{abstract}
Non-alcoholic fatty liver disease (NAFLD) is the most common cause of chronic liver disease in the Western world. NAFLD encompasses a spectrum of histological features, including steatosis, steatohepatitis with balloon degeneration, and hepatic fibrosis leading to cirrhosis. In patients with advanced liver damage, NAFLD is associated with an increased risk of hepatocellular carcinoma. Diabetes mellitus, hypertension, and dyslipidemia are components of metabolic syndrome and are commonly associated with NAFLD. Cardiovascular disease is the leading cause of mortality in patients with NAFLD. Therefore, it is important to pre-emptively identify and proactively treat conditions like hyperlipidemia in an effort to favorably modify the risk factors associated with cardiovascular events in patients with NAFLD. The management of hyperlipidemia has been shown to reduce cardiovascular mortality and improve histological damage/biochemical abnormalities associated with non-alcoholic steatohepatitis (NASH), a subset of NAFLD with advance liver damage. There are no formal guidelines available regarding the use of anti-hyperlipidemic drugs, as prospective data are lacking. The focus of this article is to discuss the utility of lipid-lowering drugs in patients with NAFLD.
\end{abstract}

Keywords: NAFLD; NASH; hepatic fibrosis; hyperlipidemia; statins

\section{Introduction}

Non-alcoholic fatty liver disease (NAFLD) is the most common cause of chronic liver disease in the developed world, and can progress to cirrhosis and hepatocellular carcinoma [1]. It is also the most common cause of elevated liver enzymes. Risk factors for NAFLD include obesity, diabetes mellitus, and hyperlipidemia. Obesity is also a significant risk factor for NAFLD, independent of hyperlipidemia, and weight loss has a beneficial effect on the prevention of hepatic fibrosis [2]. Patients with NAFLD are predisposed to cardiovascular mortality with studies demonstrating up to a twofold increase in the risk of cardiovascular disease in this population [3]. There are several hypotheses regarding the pathogenesis of NAFLD, which include insulin resistance, oxidative stress, and lipotoxicity (Figure 1). Hyperlipidemia is a significant risk factor for NAFLD and associated cardiovascular disease. The precise mechanism of action and the exact pathogenetic pathway on how hyperlipidemia increases the risk of NAFLD has not been elucidated, but may be related to an increased accumulation of lipids in the hepatocytes. Major sources of fatty acid delivery to hepatocytes include splanchnic lipolysis of visceral fat, lipogenesis, and the ingestion of fatty foods. Insulin resistance also 
downregulates low density lipoprotein (LDL)-receptor expression, leading to elevated levels of LDL. Multiple studies have shown the efficacy of lipid-lowering drugs in patients with NAFLD and its subset non-alcoholic steatohepatitis (NASH). The aim of this article is to review the medical literature on the utility of different anti-hyperlipidemic drugs in patients with NAFLD.

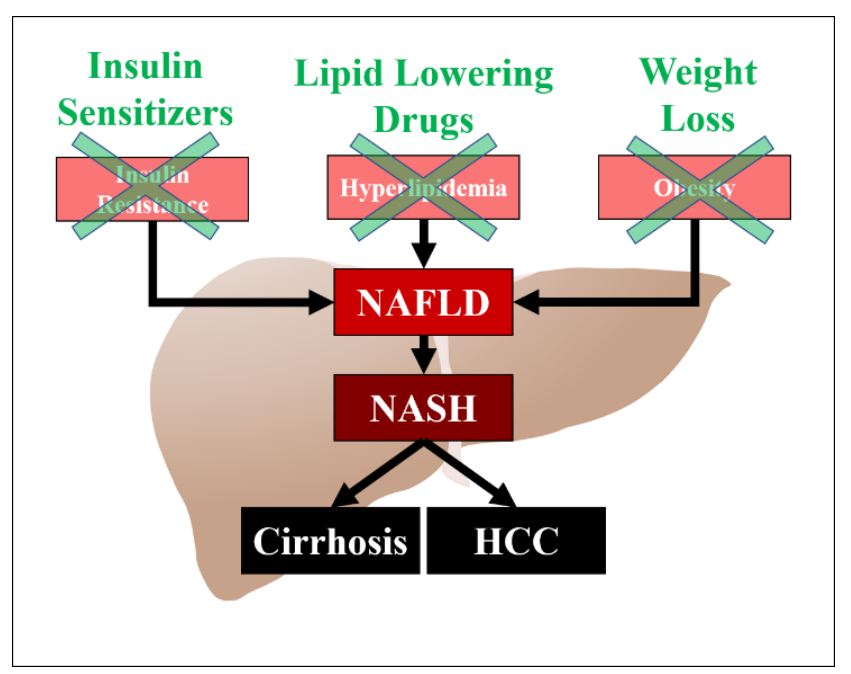

Figure 1. Pathogenesis of NAFLD/NASH and potential targets for treatment. HCC (Hepatocellular carcinoma).

\section{Lipid-Lowering Drugs}

\subsection{Statins}

Statins are the most widely used lipid lowering drugs due to their known efficacy in reducing cardiovascular mortality in patients with coronary artery disease and diabetes mellitus. These beneficial effects are not only due to the cholesterol-lowering ability of statins, but also due to their anti-inflammatory, vasodilatory (statins are nitric oxide donor), vascular remodeling, and anti-fibrotic effects independent of cholesterol-lowering activity. As inflammatory mechanisms are involved in the pathogenesis of NAFLD/NASH, statins have shown promising results decreasing liver fibrosis in patients with NAFLD. Generally, statins have been shown to be safe and effective treatment options for the indication of dyslipidemia in the context of NAFLD with the exception of Child-Pugh B and C cirrhosis and in particular if the total bilirubin level is greater than $3 \mathrm{mg} / \mathrm{dL}$ [4,5]. Table 1 summarizes the current studies evaluating the utility of different statins in NAFLD and NASH. 
Table 1. Studies evaluating the utility of Statins in non-alcoholic fatty liver disease (NAFLD)/ non-alcoholic steatohepatitis (NASH).

\begin{tabular}{|c|c|c|c|c|c|}
\hline $\begin{array}{l}\text { Author's Name and Year } \\
\text { of Publication }\end{array}$ & Drug(s) Used & Dose & $\begin{array}{l}\text { Patient Population and } \\
\text { Sample Size }\end{array}$ & $\begin{array}{c}\text { Duration of } \\
\text { Therapy }\end{array}$ & Outcome \\
\hline $\begin{array}{l}\text { Abel et al. [6] } \\
2009\end{array}$ & Simvastatin & $20 \mathrm{mg} /$ day & $\begin{array}{l}45 \text { patients with NAFLD } \\
\text { secondary to diabetes and } \\
\text { metabolic syndrome }\end{array}$ & 6 months & $\begin{array}{l}\text { Decrease in aspartate aminotransferase (AST), } \\
\text { and alanine aminotransferase (ALT) and low } \\
\text { density lipoprotein (LDL) cholesterol. Liver } \\
\text { histology was not evaluated. }\end{array}$ \\
\hline $\begin{array}{l}\text { Nelson et al. [7] } \\
2009\end{array}$ & Simvastatin & $40 \mathrm{mg} /$ day & $\begin{array}{l}16 \text { patients with } \\
\text { biopsy-proven NASH }\end{array}$ & 12 months & $\begin{array}{l}\text { No significant difference from the improvement of } \\
\text { transaminases or hepatic fibrosis. A } 26 \% \text { reduction } \\
\text { in LDL levels was seen in the simvastatin group. }\end{array}$ \\
\hline $\begin{array}{l}\text { Athyros et al. [8] } \\
2006\end{array}$ & $\begin{array}{l}\text { Atorvastatin and/or } \\
\text { Fenofibrate }\end{array}$ & $\begin{array}{l}20 \mathrm{mg} / \text { day alone or in } \\
\text { combination with } \\
\text { fenofibrate } 200 \mathrm{mg} / \text { day }\end{array}$ & $\begin{array}{l}186 \text { non-diabetic patients } \\
\text { with NAFLD and } \\
\text { metabolic syndrome }\end{array}$ & 54 weeks & $\begin{array}{c}67 \% \text { of patients on atorvastatin, } 42 \% \text { on fenofibrate, } \\
\text { and } 70 \% \text { on combination treatment no longer had } \\
\text { biochemical and ultrasonographic evidence } \\
\text { of NAFLD. }\end{array}$ \\
\hline $\begin{array}{l}\text { Foster et al. [9] } \\
\quad 2011\end{array}$ & Atorvastatin & $\begin{array}{l}20 \mathrm{mg} / \text { day along with } \\
\text { vitamin C 1g, and vitamin } \\
\text { E } 1000 \mathrm{IU}\end{array}$ & $\begin{array}{l}1005 \text { healthy men and } \\
\text { women between ages } \\
\quad 50-70\end{array}$ & $\begin{array}{l}\text { Mean follow-up } \\
3.6 \text { years }\end{array}$ & $\begin{array}{c}\text { Reduced odds of having hepatic steatosis in NAFLD } \\
\text { patients by } 71 \% .\end{array}$ \\
\hline $\begin{array}{l}\text { Gómez-Domínguez et al. } \\
{\left[\begin{array}{c}{[10]} \\
2006\end{array}\right.}\end{array}$ & Atorvastatin & $10-80 \mathrm{mg} /$ day & $\begin{array}{l}25 \text { patients with NAFLD } \\
\text { (only } 22 \text { completed } \\
\text { the study) }\end{array}$ & 6 months & $\begin{array}{l}\text { Significant improvement in aminotransferase } \\
\text { activities and cholesterol levels. }\end{array}$ \\
\hline $\begin{array}{l}\text { Kimura et al. [11] } \\
\quad 2010\end{array}$ & Atorvastatin & $10 \mathrm{mg} /$ day & $\begin{array}{l}43 \text { NASH patients with } \\
\text { dyslipidemia }\end{array}$ & 12 months & $\begin{array}{c}\text { Improvement in metabolic parameters related } \\
\text { to NASH. }\end{array}$ \\
\hline $\begin{array}{l}\text { Kiyci et al. [12] } \\
2003\end{array}$ & Atorvastatin & $10 \mathrm{mg} /$ day & 44 patients with NASH & 6 months & $\begin{array}{l}\text { Decrease in aminotransferase activity and fatty } \\
\text { infiltration of the liver. }\end{array}$ \\
\hline $\begin{array}{l}\text { Rallidis et al. [13] } \\
2004\end{array}$ & Pravastatin & $20 \mathrm{mg} /$ day & $\begin{array}{l}5 \text { patients with } \\
\text { steatohepatitis and liver } \\
\text { enzyme abnormalities }\end{array}$ & 6 months & $\begin{array}{l}\text { Improvement in histologic findings of } \\
\text { steatohepatitis. }\end{array}$ \\
\hline $\begin{array}{l}\text { Hyogo et al. [14] } \\
2011\end{array}$ & Pitavastatin & $2 \mathrm{mg} /$ day & $\begin{array}{l}20 \text { NASH patients with } \\
\text { dyslipidemia }\end{array}$ & 12 months & $\begin{array}{l}\text { Decrease in severity of hepatic steatosis. Fibrosis } \\
\text { stage improved in } 42 \% \text { of the patients. }\end{array}$ \\
\hline $\begin{array}{l}\text { Mihaila et al. [15] } \\
2009\end{array}$ & Lovastatin & $10 \mathrm{mg} /$ day & $\begin{array}{l}87 \text { patients with NASH } \\
\text { and dyslipidemia }\end{array}$ & 4 months & Decrease in aminotransferase and cholesterol levels. \\
\hline $\begin{array}{c}\text { Kargiotis et al. [16] } \\
2014\end{array}$ & Rosuvastatin & $10 \mathrm{mg} /$ day & $\begin{array}{l}6 \text { non-diabetic patients } \\
\text { with NASH, metabolic } \\
\text { syndrome, } \\
\text { and dyslipidemia }\end{array}$ & 12 months & $\begin{array}{l}\text { Resolution of ultrasonographic findings of NASH. } \\
\text { Improvement in aminotransferases; ALT and AST } \\
\text { levels were reduced by } 76 \% \text { and } 61 \% \text {, respectively. }\end{array}$ \\
\hline $\begin{array}{l}\text { Kargiotis et al. [17] } \\
2015\end{array}$ & Rosuvastatin & $10 \mathrm{mg} /$ day & $\begin{array}{l}20 \text { patients with NASH, } \\
\text { metabolic syndrome, } \\
\text { and dyslipidemia }\end{array}$ & 12 months & Resolution of ultrasonographic findings of NASH. \\
\hline $\begin{array}{l}\text { Nakahara et al. [18] } \\
2012\end{array}$ & Rosuvastatin & $2.5 \mathrm{mg} /$ day & $\begin{array}{l}19 \text { patients with NASH } \\
\text { and dyslipidemia }\end{array}$ & 24 months & $\begin{array}{c}\text { Improvement of NASH-related parameters, } \\
\text { with } 33.3 \% \text { patients showing improvement in } \\
\text { non-alcoholic fatty liver disease activity score and } \\
\text { fibrotic stage. }\end{array}$ \\
\hline
\end{tabular}




\subsection{Simvastatin}

Multiple studies have shown safety and efficacy results of simvastatin in patients with NAFLD and NASH. Abel et al. conducted a study on a small group of NAFLD patients and revealed that simvastatin at $20 \mathrm{mg} /$ day for 6 months significantly decreased aspartate aminotransferase (AST), alanine aminotransferase (ALT), and LDL cholesterol levels in these patients [6]. Liver histological evaluation was not done in this study. In another randomized controlled trial, simvastatin at $40 \mathrm{mg}$ /day for 12 months was compared with a placebo, which significantly reduced LDL cholesterol levels [7]. Although patient cholesterol levels were lowered in the simvastatin group, no significant differences were found in levels of transaminases or hepatic fibrosis.

\subsection{Atorvastatin}

Several clinical studies reported the safety and efficacy of atorvastatin in NAFLD/NASH patients [8-12]. A randomized controlled trial comparing atorvastatin with the combination of atorvastatin and fenofibrate or fenofibrate alone revealed that atorvastatin alone or in combination with fenofibrate could improve liver enzymes and ultrasonographic features of NAFLD [8]. In a St. Francis Heart study, atorvastatin along with vitamins $C$ and $E$ was associated with reduced likelihood of developing hepatic steatosis in patients with NAFLD [9]. Although the results of this study were promising, they may be confounded by the use of vitamin E, as vitamin $\mathrm{E}$ alone has been shown to be beneficial in NAFLD patients [19]. In a study by Gomez-Dominguez, 22 hyperlipidemic NAFLD patients received 10-80 mg/day of atorvastatin for 6 months and showed significant improvement in aminotransferase and cholesterol levels [10]. Kimura et al. reported the role of advanced glycation end products (AGEs) in NASH, as the levels of these products were significantly high in NASH patients. Treatment of patients with atorvastatin resulted in a significant decrease in AGE levels and an improvement in metabolic parameters related to NASH [11]. In a study done on 27 biopsy-proven NASH patients with hyperlipidemia, Kiyci et al. revealed the promising effects of atorvastatin $10 \mathrm{mg} /$ day for 6 months [12]. Atorvastatin was shown to decrease aminotransferase activity and significantly decrease fatty infiltration of the liver. These studies favor the beneficial effects of atorvastatin in NAFLD patients.

\subsection{Pravastatin}

The current evidence regarding the use of pravastatin in NAFLD patients is lacking. In a study on five patients with biopsy-proven steatohepatitis, Rallidis et al. revealed that the use of pravastatin resulted in an improvement of hepatic histological findings [13]. Further studies - especially randomized controlled trials—are needed to further investigate the utility of pravastatin in NAFLD patients.

\subsection{Pitavastatin}

Pitavastatin has been indicated to be beneficial in inhibiting hepatic fibrosis in NASH rat models, but research on its utility in patients with NAFLD is still too premature to make any conclusions. Hyogo et al. conducted an open-label pilot study that revealed $2 \mathrm{mg}$ /day of pitavastatin for 12 months decreased the severity of hepatic steatosis and NASH-related parameters [14]. Although the study results are promising, further studies are necessary to support these findings.

\subsection{Lovastatin}

In a multicentric prospective study, $10 \mathrm{mg} /$ day of lovastatin for four months was shown to significantly decrease transaminases, cholesterol levels, and aminotransferase to platelet ratio indices [15]. Again, more studies are needed to support the beneficial effects of lovastatin in NAFLD patients. 


\subsection{Rosuvastatin}

In a preliminary report on six patients with NASH, $10 \mathrm{mg} /$ day of rosuvastatin for 12 months not only showed improvement in AST and ALT levels, but also the complete resolution of ultrasonographic findings of NASH in five patients [16]. Similar beneficial effects were seen in a prospective study on 20 patients, in which $10 \mathrm{mg}$ /day of rosuvastatin for 12 months resulted in the complete resolution of ultrasonographic findings of NASH in 19 patients [17]. Nakahara et al. also revealed beneficial effects of $2.5 \mathrm{mg} /$ day of rosuvastatin for 24 months, and showed an improvement of NASH-related parameters and histological features in some patients [18].

\subsection{Non-Statin Lipid Lowering Drugs}

Table 2 summarizes the current evidence regarding the utility of lipid-lowering drugs other than statins in patients with NAFLD and NASH. 
Table 2. Studies evaluating the utility of lipid-lowering drugs in NAFLD/NASH.

\begin{tabular}{|c|c|c|c|c|c|}
\hline $\begin{array}{l}\text { Author's Name and } \\
\text { Year of Publication }\end{array}$ & Drug(s) Used & Dose & $\begin{array}{l}\text { Patient Population and } \\
\text { Sample Size }\end{array}$ & Duration of Therapy & Outcome \\
\hline $\begin{array}{l}\text { Athyros et al. [8] } \\
\quad 2006\end{array}$ & $\begin{array}{l}\text { Fenofibrate alone or in } \\
\text { combination with } \\
\text { atorvastatin }\end{array}$ & $\begin{array}{l}200 \mathrm{mg} / \text { day alone or in } \\
\text { combination with } \\
\text { atorvastatin } 20 \mathrm{mg} / \text { day }\end{array}$ & $\begin{array}{l}186 \text { non-diabetic patients } \\
\text { with NAFLD and } \\
\text { metabolic syndrome }\end{array}$ & 54 weeks & $\begin{array}{l}42 \% \text { of the patients in the fenofibrate-only treatment } \\
\text { group had a complete resolution of biochemical and } \\
\text { ultrasonographic evidence of NAFLD. }\end{array}$ \\
\hline $\begin{array}{l}\text { Basarangolu et al. [20] } \\
1999\end{array}$ & Gemfibrozil & $600 \mathrm{mg} /$ day & $\begin{array}{l}46 \text { patients with NASH } \\
\text { and liver enzyme } \\
\text { abnormalities }\end{array}$ & 4 weeks & $\begin{array}{l}\text { Lower levels of ALT, AST, and gamma glutamyl } \\
\text { transferase (GGT). No change in liver histology. }\end{array}$ \\
\hline $\begin{array}{c}\text { Laurin et al. [21] } \\
\qquad 1996\end{array}$ & Clofibrate & $2 \mathrm{~g} /$ day & 40 patients with NASH & 12 months & No improvement in aminotransferase activities. \\
\hline $\begin{array}{l}\text { Fernandez-Miranda } \\
\text { et al. [22] } \\
2008\end{array}$ & Fenofibrate & $200 \mathrm{mg} /$ day & 16 NAFLD patients & 48 weeks & $\begin{array}{l}\text { Decrease in insulin resistance, aminotransferases } \\
\text { levels, and signs of metabolic syndrome. } \\
\text { No significant effect on liver histology. }\end{array}$ \\
\hline $\begin{array}{l}\text { Ratziu et al. [23] } \\
\quad 2016\end{array}$ & Elafibranor & $120 \mathrm{mg} /$ day & $\begin{array}{l}276 \text { patients with NASH } \\
\text { without cirrhosis }\end{array}$ & 52 weeks & $\begin{array}{l}\text { Resolution of NASH without fibrosis worsening in } \\
\text { the greater proportion of patients compared to } \\
\text { placebo }(19 \% \text { vs. } 12 \% \text {; odds ratio }=2.31 ; p=0.045) \text {. }\end{array}$ \\
\hline $\begin{array}{l}\text { Fabbrini et al. [24] } \\
\qquad 2010\end{array}$ & Niacin & $2000 \mathrm{mg} /$ day & $\begin{array}{l}27 \text { obese patients } \\
\text { with NAFLD }\end{array}$ & 16 weeks & $\begin{array}{l}\text { Lowered plasma levels of very-low density } \\
\text { lipoprotein (VLDL)-TGs but no change in } \\
\text { intrahepatic triglycerides (TGs) content. }\end{array}$ \\
\hline $\begin{array}{l}\text { Yoneda et al. [25] } \\
\quad 2010\end{array}$ & Ezetimibe & $10 \mathrm{mg} /$ day & $\begin{array}{l}10 \text { patients with NASH } \\
\text { and dyslipidemia }\end{array}$ & 6 months & $\begin{array}{l}\text { Improvement in hepatic steatosis and histological } \\
\text { findings. } 6 \text { out of } 10 \text { patients showed improvement } \\
\text { in their fibrosis stage. }\end{array}$ \\
\hline $\begin{array}{l}\text { Park et al. [26] } \\
\quad 2011\end{array}$ & Ezetimibe & $10 \mathrm{mg} /$ day & 45 NAFLD patients & 24 months & $\begin{array}{l}\text { Improvement in biochemical and histological } \\
\text { abnormalities of NAFLD. }\end{array}$ \\
\hline $\begin{array}{l}\text { Chan et al. [27] } \\
\qquad 2010\end{array}$ & Ezetimibe & $10 \mathrm{mg} /$ day & $\begin{array}{l}25 \text { patients with } \\
\text { central obesity }\end{array}$ & 16 weeks & Improvement in hepatic steatosis. \\
\hline $\begin{array}{l}\text { Spadro et al. [28] } \\
\quad 2008\end{array}$ & $\begin{array}{l}\text { Omega- } 3(\mathrm{n}-3) \\
\text { polyunsaturated fatty } \\
\text { acids (PUFAs) }\end{array}$ & $2 \mathrm{~g} /$ day & 40 patients with NAFLD & 6 months & $\begin{array}{c}\text { Improvement in serum AST, ALT, triglyceride levels, } \\
\text { and fatty liver. }\end{array}$ \\
\hline $\begin{array}{l}\text { Capanni et al. [29] } \\
2006\end{array}$ & n-3 PUFAs & $1 \mathrm{~g} /$ day & 56 patients with NAFLD & 12 months & $\begin{array}{l}\text { Improvement of AST, ALT, GGT, triglycerides, } \\
\text { and ultrasonographic features of hepatic steatosis. }\end{array}$ \\
\hline
\end{tabular}




\subsection{Fibrates}

Fibrates or fibric acid derivatives are used to treat hypertriglyceridemia and primary hypercholesterolemia, mainly by activating peroxisome proliferator-activated receptor alpha (PPAR-alpha). Multiple studies have been done to evaluate the safety and efficacy of these agents in treating hyperlipidemia in NAFLD/NASH patients [8,20-22]. In a prospective open-label randomized study, Athyros et al. included 186 patients that were randomly assigned to receive either $20 \mathrm{mg} / \mathrm{day}$ of atorvastatin, $200 \mathrm{mg} /$ day of fenofibrate, or both [8]. A complete resolution of biochemical and ultrasonographic evidence of NAFLD was seen in $42 \%$ of the patients in the fenofibrate group compared to $67 \%$ of patients taking atorvastatin alone, and $70 \%$ in the combination therapy group [8]. In a randomized controlled trial (RCT), Basarangolu et al. included 23 patients taking $600 \mathrm{mg} /$ day of gemfibrozil for four weeks, and compared these with 23 placebo patients who were not treated with any lipid-lowering drugs. Patients in the gemfibrozil group had significantly lower levels of AST, ALT, and GGT without any significant changes in liver histology [20]. Laurin et al. evaluated the utility of the fibric acid derivative clofibrate in $16 \mathrm{NASH}$ patients with hyperlipidemia taking $2 \mathrm{~g} /$ day [21]. The study did not find any improvement in aminotransferases, GGT, or bilirubin levels. In a pilot study on 16 biopsy-proven NAFLD patients, Fernandez-Miranda et al. revealed that $200 \mathrm{mg} / \mathrm{day}$ of fenofibrate for 48 weeks resulted in decreased insulin resistance, aminotransferases levels, and signs of metabolic syndrome [22]. Although the drug showed promising results in decreasing the proportion of patients with metabolic syndrome, its effect on liver histology was minimal. Hence, considering current evidence, we conclude that the utility of fibrates and fibric acid derivatives in ameliorating the histological features of NAFLD is still unclear and requires further studies.

\subsection{Elafibranor}

Elafibranor is an activator of both Peroxisome proliferator-activated receptor (PPAR)- $\alpha$ and PPAR- $\delta$ that has anti-inflammatory effects and helps to improve lipid metabolism and insulin resistance. In a randomized controlled double-blind trial, 276 patients with NASH were divided into three groups to receive either $80 \mathrm{mg} /$ day of elafibranor, $120 \mathrm{mg}$ /day of elafibranor, or a placebo for 52 weeks [23]. Aminotransferase activity, glucose levels, and inflammatory markers were significantly lower in the elafibranor $120 \mathrm{mg}$ group compared to the placebo group. A post-hoc analysis of the study also revealed that elafibranor $(120 \mathrm{mg} / \mathrm{d}$ for 1 year) resolved NASH without fibrosis worsening in the greater proportion of patients compared to placebo, but there was no difference in the outcome in the intention-to-treat analysis [23]. These results are encouraging for the use of elafibranor in NASH patients, but require further studies - especially randomized controlled trials-to further strengthen the evidence of these beneficial effects.

\subsection{Niacin}

Niacin (nicotinic acid or vitamin B-3) is used to treat vitamin deficiency (pellagra) and has lipid-lowering effects. The mechanism by which these drugs exert their lipid-lowering effects is still unclear. Fabbrini et al. reported that the combination of $200 \mathrm{mg} /$ day of fenofibrate for 8 weeks and extended-release niacin at $2000 \mathrm{mg}$ /day for 16 weeks lowered the plasma levels of VLDL-triglycerides, but did not alter intrahepatic triglyceride content [24]. The safety and efficacy of niacin in NAFLD patients has yet to be established, and requires further clinical studies.

\subsection{Ezetimibe}

Ezetimibe exerts its lipid-lowering effects by inhibiting small intestinal absorption of cholesterol via its effects on the sterol transporter Niemann-Pick C1-Like1 (NPC1L1). These molecules are also expressed in the liver, and play a role in hepatic cholesterol accumulation. The combination of ezetimibe and statins has been shown to improve LDL cholesterol levels in patients with hypercholesterolemia. In one study, Yoneda et al. reported $10 \mathrm{mg} /$ day of ezetimibe for 6 months in NASH patients with 
hyperlipidemia resulted in significant improvement in histological findings, NAFLD activity scores, and steatosis in the liver [25]. They also revealed improvement in AST, ALT, GGT, LDL cholesterol levels, and C-reactive protein (CRP) in these patients. Similar results were seen in a study done by Park et al. regarding 45 patients with biopsy-proven NAFLD [26]. They reported that $10 \mathrm{mg} / \mathrm{day}$ of ezetimibe for 24 months improved the biochemical and histological abnormalities of NAFLD. Chan et al. also reported that weight loss along with ezetimibe was associated with an improvement in hepatic steatosis [27]. These study results favor the use of ezetimibe in NAFLD/NASH patients with hyperlipidemia, as it might ameliorate the biochemical and histological features of NAFLD.

\subsection{Omega-3 (n-3) Polyunsaturated Fatty Acids (PUFAs)}

The use of n-3 PUFAs increases the levels of adiponectin in the blood and decreases serum levels of triglycerides, leptin, and insulin, which promote weight loss and improve insulin resistance [28,29]. In a study of 40 patients with NAFLD, Spadro et al. reported improvement in serum AST, ALT, triglyceride levels, and fatty liver with the use of n-3 PUFAs [28]. Similar beneficial effects were seen in a study by Capanni et al., which reported that n-3 PUFA supplementation of $1 \mathrm{~g} / \mathrm{day}$ for 12 months resulted in the improvement of AST, ALT, GGT, triglycerides, and ultrasonographic features of hepatic steatosis [29]. Current evidence is therefore encouraging, but further studies are needed to define the utility of n-3 PUFAs for management of NAFLD.

\section{Conclusions}

Statins have been shown to be most beneficial in the prevention of hepatic fibrosis in patients with NAFLD/NASH. Hence, in light of current evidence, we recommend considering statins and vitamin $\mathrm{E}$ along with weight loss and exercise in these patients. Although evidence regarding the utility of lipid-lowering drugs in patients with NAFLD/NASH is convincing, with most studies reporting that lipid-lowering drug use showed an improvement in hepatic steatosis, formal guidelines are lacking in this regard-mainly due to the absence of larger randomized controlled trials. Despite the need for more randomized controlled trials regarding these drugs, our review will help guide clinicians in prescribing lipid-lowering agents in NAFLD patients. This, in turn, may help decrease the morbidity and mortality associated with this serious disease.

Author Contributions: Writing-Original Draft Preparation, U.I., B.J.P., G.C., N.J., S.S., N.D.S., W.K., A.A.; Writing-Review \& Editing, D.K., A.A.; Supervision, A.A.

Funding: There were no funding sources for this study.

Conflicts of Interest: The authors declare no conflicts of interest, including financial and/or material support for the preparation of this manuscript.

\section{References}

1. Loomba, R.; Sanyal, A.J. The global NAFLD epidemic. Nat. Rev. Gastroenterol. Hepatol. 2013, 10, 686-690. [CrossRef] [PubMed]

2. Li, L.; Liu, D.-W.; Yan, H.-Y.; Wang, Z.-Y.; Zhao, S.-H.; Wang, B. Obesity is an independent risk factor for non-alcoholic fatty liver disease: Evidence from a meta-analysis of 21 cohort studies. Obes. Rev. 2016, 17, 510-519. [CrossRef] [PubMed]

3. Ballestri, S.; Lonardo, A.; Bonapace, S.; Byrne, C.D.; Loria, P.; Targher, G. Risk of cardiovascular, cardiac and arrhythmic complications in patients with non-alcoholic fatty liver disease. World J. Gastroenterol. 2014, 20, 1724-1745. [CrossRef] [PubMed]

4. Sigler, M.A.; Congdon, L.; Edwards, K.L. An evidence-based review of statin use in patients with nonalcoholic fatty liver disease. Clin. Med. Insights Gastroenterol. 2018, 11. [CrossRef] [PubMed]

5. Magan-Fernandez, A.; Rizzo, M.; Montalto, G.; Marchesini, G. Statins in liver disease: Not only prevention of cardiovascular events. Expert Rev. Gastroenterol. Hepatol. 2018, 12, 743-744. [CrossRef] [PubMed] 
6. Abel, T.; Fehér, J.; Dinya, E.; Eldin, M.G.; Kovács, A. Safety and efficacy of combined ezetimibe/simvastatin treatment and simvastatin monotherapy in patients with non-alcoholic fatty liver disease. Med. Sci. Monitor 2009, 15, MS6-11.

7. Nelson, A.; Torres, D.M.; Morgan, A.E.; Fincke, C.; Harrison, S.A. A pilot study using simvastatin in the treatment of nonalcoholic steatohepatitis: A randomized placebo-controlled trial. J. Clin. Gastroenterol. 2009, 43, 990-994. [CrossRef] [PubMed]

8. Athyros, V.G.; Mikhailidis, D.P.; Didangelos, T.P.; Giouleme, O.I.; Liberopoulos, E.N.; Karagiannis, A.; Kakafika, A.I.; Tziomalos, K.; Burroughs, A.K.; Elisaf, M.S. Effect of multifactorial treatment on non-alcoholic fatty liver disease in metabolic syndrome: A randomised study. Curr. Med. Res. Opin. 2006, 22, 873-883. [CrossRef] [PubMed]

9. Foster, T.; Budoff, M.J.; Saab, S.; Ahmadi, N.; Gordon, C.; Guerci, A.D. Atorvastatin and antioxidants for the treatment of nonalcoholic fatty liver disease: The St Francis heart study randomized clinical trial. Am. J. Gastroenterol. 2011, 106, 71-77. [CrossRef] [PubMed]

10. Gómez-Domínguez, E.; Gisbert, J.P.; Moreno-Monteagudo, J.A.; García-Buey, L.; Moreno-Otero, R. A pilot study of atorvastatin treatment in dyslipemid, non-alcoholic fatty liver patients. Aliment. Pharm. Therap. 2006, 23, 1643-1647. [CrossRef] [PubMed]

11. Kimura, Y.; Hyogo, H.; Yamagishi, S.-I.; Takeuchi, M.; Ishitobi, T.; Nabeshima, Y.; Arihiro, K.; Chayama, K. Atorvastatin decreases serum levels of advanced glycation endproducts (AGEs) in nonalcoholic steatohepatitis (NASH) patients with dyslipidemia: Clinical usefulness of AGEs as a biomarker for the attenuation of NASH. J. Gastroenterol. 2010, 45, 750-757. [CrossRef] [PubMed]

12. Kiyici, M.; Gulten, M.; Gurel, S.; Nak, S.G.; Dolar, E.; Savci, G.; Adim, S.B.; Yerci, O.; Memik, F. Ursodeoxycholic acid and atorvastatin in the treatment of nonalcoholic steatohepatitis. Can. J. Gastroenterol. 2003, 17, 713-718. [CrossRef] [PubMed]

13. Rallidis, L.S.; Drakoulis, C.K.; Parasi, A.S. Pravastatin in patients with nonalcoholic steatohepatitis: Results of a pilot study. Atherosclerosis 2004, 174, 193-196. [CrossRef] [PubMed]

14. Hyogo, H.; Ikegami, T.; Tokushige, K.; Hashimoto, E.; Inui, K.; Matsuzaki, Y.; Tokumo, H.; Hino, F.; Tazuma, S. Efficacy of pitavastatin for the treatment of non-alcoholic steatohepatitis with dyslipidemia: An open-label, pilot study. Hepatol. Res. 2011, 41, 1057-1065. [CrossRef] [PubMed]

15. Mihaila, R.-G.; Nedelcu, L.; Fratila, O.; Rezi, E.-C.; Domnariu, C.; Deac, M. Effects of lovastatin and pentoxyphyllin in nonalcoholic steatohepatitis. Hepato-Gastroenterol. 2009, 56, 1117-1121.

16. Kargiotis, K.; Niki, K.; Athyros, V.G.; Giouleme, O.; Patsiaoura, K.; Katsiki, E.; Mikhailidis, D.P.; Karagiannis, A. Effect of rosuvastatin on non-alcoholic steatohepatitis in patients with metabolic syndrome and hypercholesterolaemia: A preliminary report. Curr. Vasc. Pharm. 2014, 12, 505-511. [CrossRef]

17. Kargiotis, K.; Athyros, V.G.; Giouleme, O.; Katsiki, N.; Katsiki, E.; Anagnostis, P.; Boutari, C.; Doumas, M.; Karagiannis, A.; Mikhailidis, D.P. Resolution of non-alcoholic steatohepatitis by rosuvastatin monotherapy in patients with metabolic syndrome. World J. Gastroenterol. 2015, 21, 7860-7868. [CrossRef] [PubMed]

18. Nakahara, T.; Hyogo, H.; Kimura, Y.; Ishitobi, T.; Arihiro, K.; Aikata, H.; Takahashi, S.; Chayama, K. Efficacy of rosuvastatin for the treatment of non-alcoholic steatohepatitis with dyslipidemia: An open-label, pilot study. Hepatol. Res. 2012, 42, 1065-1072. [CrossRef] [PubMed]

19. Sanyal, A.J.; Chalasani, N.; Kowdley, K.V.; McCullough, A.; Diehl, A.M.; Bass, N.M.; Neuschwander-Tetri, B.A. Pioglitazone, vitamin E, or placebo for nonalcoholic steatohepatitis. New Engl. J. Med. 2010, 362, 1675-1685. [CrossRef] [PubMed]

20. Basaranoglu, M.; Acbay, O.; Sonsuz, A. A controlled trial of gemfibrozil in the treatment of patients with nonalcoholic steatohepatitis. J. Hepatol. 1999, 31, 384. [CrossRef]

21. Laurin, J.; Lindor, K.D.; Crippin, J.S.; Gossard, A.; Gores, G.J.; Ludwig, J.; Rakela, J.; McGill, D.B. Ursodeoxycholic acid or clofibrate in the treatment of non-alcohol-induced steatohepatitis: A pilot study. Hepatology 1996, 23, 1464-1467. [CrossRef] [PubMed]

22. Fernández-Miranda, C.; Pérez-Carreras, M.; Colina, F.; López-Alonso, G.; Vargas, C.; Solís-Herruzo, J.A. A pilot trial of fenofibrate for the treatment of non-alcoholic fatty liver disease. Dig. Liver Dis. 2008, 40, 200-205. [CrossRef] [PubMed] 
23. Ratziu, V.; Harrison, S.A.; Francque, S.; Bedossa, P.; Lehert, P.; Serfaty, L.; Romero-Gomez, M.; Boursier, J.; Abdelmalek, M.; Caldwell, S.; et al. Elafibranor, an agonist of the peroxisome proliferator-activated receptor- $\alpha$ and $-\delta$, induces resolution of nonalcoholic steatohepatitis without fibrosis worsening. Gastroenterology 2016, 150, 1147-1159. [CrossRef] [PubMed]

24. Fabbrini, E.; Mohammed, B.S.; Korenblat, K.M.; Magkos, F.; McCrea, J.; Patterson, B.W.; Klein, S. Effect of fenofibrate and niacin on intrahepatic triglyceride content, very low-density lipoprotein kinetics, and insulin action in obese subjects with nonalcoholic fatty liver disease. J. Clin. Endocrinol. Metab. 2010, 95, 2727-2735. [CrossRef] [PubMed]

25. Yoneda, M.; Fujita, K.; Nozaki, Y.; Endo, H.; Takahashi, H.; Hosono, K.; Suzuki, K. Efficacy of ezetimibe for the treatment of non-alcoholic steatohepatitis: An open-label, pilot study. Hepatol. Res. 2010, 40, 566-573. [CrossRef] [PubMed]

26. Park, H.; Shima, T.; Yamaguchi, K.; Mitsuyoshi, H.; Minami, M.; Yasui, K.; Itoh, Y.; Yoshikawa, T.; Fukui, M. Efficacy of long-term ezetimibe therapy in patients with nonalcoholic fatty liver disease. J. Gastroenterol. 2011, 46, 101-107. [CrossRef] [PubMed]

27. Chan, D.C.; Watts, G.F.; Gan, S.K.; Ooi, E.M.M.; Barrett, P.H.R. Effect of ezetimibe on hepatic fat, inflammatory markers, and apolipoprotein B-100 kinetics in insulin-resistant obese subjects on a weight loss diet. Diabetes Care 2010, 33, 1134-1139. [CrossRef] [PubMed]

28. Spadaro, L.; Magliocco, O.; Spampinato, D.; Piro, S.; Oliveri, C.; Alagona, C.; Papa, G.; Rabuazzo, A.M.; Purrello, F. Effects of N-3 polyunsaturated fatty acids in subjects with nonalcoholic fatty liver disease. Dig. Liver Dis. 2008, 40, 194-199. [CrossRef] [PubMed]

29. Capanni, M.; Calella, F.; Biagini, M.R.; Genise, S.; Raimondi, L.; Bedogni, G.; Svegliati-Baroni, G.; Sofi, F.; Milani, S.; Abbate, R.; et al. Prolonged N-3 polyunsaturated fatty acid supplementation ameliorates hepatic steatosis in patients with non-alcoholic fatty liver disease: A pilot study. Aliment. Pharm. Therap. 2006, 23, 1143-1151. [CrossRef] [PubMed]

(C) 2018 by the authors. Licensee MDPI, Basel, Switzerland. This article is an open access article distributed under the terms and conditions of the Creative Commons Attribution (CC BY) license (http:/ / creativecommons.org/licenses/by/4.0/). 